\title{
KOMUNIKASI MORAL RELIGIUS MELALUI DONGENG PADA SELAPARANG TV
}

\author{
Ahmad Hamdian Alfi \\ Email: hamdianahmad@gmail.com
}

\begin{abstract}
This paper uses a case study approach, in addition to obtaining valid data, the author here collects data with structured interview techniques, full participant observation and documentationanalysis. Communicationisusedbystorytellers in conveying moral messages through the Selaparang TV media namely verbal and nonverbal communication. Verbal communication is used when narrating or telling fairy tales, while nonverbal communication is used in the form of illustrations from fairy tales brought. The communication process that occurs in the field is secondary communication where storytellers convey moral messages through television media. The moral message conveyed is more about the stories of prophet Muhammad SAW.
\end{abstract}

Keywords: Storytelling Communication, Moral Religious Message, Television 


\begin{abstract}
Abstrak
Tulisan ini menggunakan pendekatan kajian studi kasus, selain itu untuk mendapatkan data yang valid, penulis di sini mengumpulkan data dengan teknik wawancara terstruktur, observasi partisipan penuh dan analisa dokumentasi. Komunikasi yang digunakan pendongeng dalam menyampaikan pesan moral melaui media Selaparang TV yakni komunikasi verbal dan nonverbal. Komunikasi verbal digunakan ketika mengisahkan atau menceritakan dongeng-dongeng, sedangkan komunikasi nonverbal digunakan dalam bentuk gambar-gambar ilustrasi dari dongeng yang dibawakan. Proses komunikasi yang terjadi di lapangan adalah komunikasi skunder di mana pendongeng menyampaikan pesan moral melalui media televisi. Pesan moral yang disampaikan lebih banyak membahas tentang kisah-kisah nabi Muhammad SAW.
\end{abstract}

Kata Kunci: Komunikasi Pendongeng, Pesan Moral Religi, Televisi

\section{A. Pendahuluan}

Media televisi merupakan salah satu media elektronik yang paling digemari saat ini. Di zaman serba modern ini, televisi bukan hanya berfungsi sebagai sumber informasi saja, melainkan juga berfungsi sebagai media hiburan, promosi, bahkan menjadi salah satu sumber perekonomian. Peter Golding dan Graham Murdoc sebagaimana di kutip Agus Sudibyo menyebutkan, media tidak hanya memilki fungsi sosial dan ekonomi, tetapi juga menjalankan fungsi ideologis. ${ }^{1}$

1 Agus Sudibyo, Ekonomi Politik Media Penyiaran, (Yogyakarta, LkiS, 2004), 1
Perkembangan menuju zaman media massa telah membawa dunia pada zaman yang baru. Kehadiran televisi di masyarakat membuat perubahan yang spektakuler dalam kehidupan masyarakat, khususnya di Indonesia. Pergaulan masyarakat sehari-hari hampir semuanya berkiblat ke perkotaan, mulai dari pakaian, gaya bahasa dan bahkan prilaku sehari-hari.

Media massa saat ini sudah menjadi kebutuhan utama, kebutuhan akan informasi setiap hari baik informasi dari dalam maupun luar negeri. Seiring perkembangan zaman program siaran yang ditayangkan oleh media TV semakin 
beragam, mulai dari berita, hiburan dan informasi lainnya. Selain tayangan yang menghibur, media TV mudah diterima masyarakat karena jangkauannya sampai ruangruang pribadi seseorang.

Teknologi komunikasi TV sering dijuluki sebagai faktor penentu perubahan yang kehadirannya tidak bisa dibendung, makin mendekati abad ke-21, makin banyak pula perubahan yang terjadi akibat kemajuan teknologi komunikasi media televisi. Proses pengaruh ini tidak berjalan pada satu bidang saja, tapi juga merambah ke bidang-bidang lain yang ada dalam kehidupan manusia. ${ }^{2}$ Tayangan TV di Indonesia saat ini masih di dominasi oleh sinetron-sinetron, FTV, berita infotaimen, dan kuis untuk menarik pemirsa.

Jika memperhatikan lebih jauh, program siaran TV sekarang lebih mengutamakan iklan sehingga fungsi edukasi dalam siaran sangat minim, hanya beberapa persen saja dari semua program. Bahkan seringkali TV sekarang menyiarkan program yang menyangkut kepribadian orang lain, sebagaimana disiarkan dalam beberapa program infotainment beberapa tahun lalu. Selain infotainmen tayangan sinetron

2 Wawan Kuswandi, Komunikasi Massa Sebuah Analisis Media Televisi, (Jakarta: Rineka Cipta,1996), 19 juga seringkali menayangkan adegan yang melanggar undang-undang penyiaran, belum lama ini ada beberapa sinetron yang mendapat surat teguran dari KPID terkait tayangannya yang antisosial dan tidak layak ditonton, khususnya bagi anakanak karena memuat adegan-adegan yang tidak layak di pertontonkan. Sinetron-sinetron andalan dari sebuah stasiun TV diatayangkan ketika jam tayang untuk anaka-anak seperti pada waktu malam dari pukul 18:00 hingga pukul 22:00, sedangkan pada jam ini anak-anak biasanya anak-anak belum tidur, sehingga anak-anak seringkali melalaikan tugas dan kewajiban demi untuk menonto program kesukaannya. Khususnya bagi anak-anak muslim yang melaksanakan kegiatan agama seperti mengaji dan sholat. Produser dan rumah produksi juga perlu diawasi agar tidak mengekploitasi dunia anak-anak dalam membuat film anak-anak.

Lain halnya dengan Selaparang TV, berdasarkan hasil observasi awal ${ }^{3}$ Penulis menemukanbahwa tayangan yang ada di Selaparang TV berbeda dengan stasiun TV nasional, ditengah persaingan media kapitaslis yang hanya mengutamakan kepentingan pribadi, stasiun TV lokal ini malah lebih mengutamakan budaya, tradisi, kearifan lokal dan edukasi.

3 Observasi awal 14 Oktober 2017 
Sehingga program acara yang di tayangkan lebih kepada kebutuhan masyarakat, lebih mendidik dan lebih mengutamakan norma-norma, khususnya dalam menayangkan program untuk masyarakat Lombok Timur. Mulai dari jenis acara, cara penyampaian dan setting acaranya memang sangat mendukung proses edukasi dan imajinasi khususnya untuk anak-anak.

\section{B. Beberapa Pendekatan Dalam Komunikasi}

Teori pertama disebut Operant Conditioningyangdikembangkanoleh seorang ahli psikologi behavioristik yang bernama B. F. Skinner. Teori ini menekankan unsur rangsangan (stimulus) dan tanggapan (response) atau lebih dikenal dengan istilah S-R. teori ini menyatakan bahwa jika satu organisme dirangsang dari luar, orang cenderung akan memberikan reaksi. Anak-anak mengetahui bahasa karena ia diajar oleh orang tuanya atau meniru apa yang diucapkan oleh orang lain.

Teori kedua ialah teori Kognitif yang dikembangkan oleh Noam Chomsky. Menurutnya kemampuan berbahasa yang ada pada manusia adalah pembawaan biologis yang dibawa dari lahir. Teori ketiga disebut Mediating theory atau teori penengah, dikembangkan oleh Charles Osgood. Teori ini menekankan bahwa manusia dalam mengembangkan kemampuannya berbahasa, tidak saja bereaksi terhadap rangsangan (stimulti) yang diterima dari luar, tetapi juga dipengaruhi oleh proses internal yang terjadi dalam dirinya. ${ }^{4}$

\section{Media Siaran TV}

Dalam menyiarkan program, tentunya sebelum penayangannya dilakukan perumusan konsep program, berbicara tentang konsep tentunya dibutuhkan survei terlebih dahulu untuk mendapatkan konsep siaran yang akan dijalankan oleh peusahaan media TV. Mulai dari proses perencanaan, penyusunan naskah, perekaman dan proses siaran program acara melalui stasiun TV.

Setelah melakukan siaran tentunya dibutuhkan pengujian untuk program siaran yang ditayangkan, ada beberapa cara untuk melakukan evaluasi program antara lain:

Various Commitees (komite pendidikan dll), Study Meetings (pertemuan bedah program), Viewers meeting (pertemuan pemirsa), Monitoring, Telephone cells (melalui telepon), Latters (melalui surat), Survey ${ }^{5}$

4 H. Hafied Cangara, Pengantar Ilmu Komunikasi, (Jakarta: Raja Grafindo Perkasa, 2007), 99-102

5 Hery Kuswita "Perencanaan dan Produksi Program Televisi Pendidikan 
Siaran TV anak pada zaman sekarang sudah sangat banyak, selain film kartun program tayangan anak sekarang juga di dominasi oleh program-program unggulan seperti Si Bolang, Dunia air, dan masih banyak lagi. Selain itu, dari beberapa jurnal yang ditulis oleh mahasiswa tentang film favorit anakanak juga terdiri dari anime-anime dan violence kartun. Reni Triwandi dalam jurnalnya menjelaskan dari hasil Penulisannya ia menemukan bahwa masing-masing informan memiliki preferensi program kartun favoritnya sendiri. Kebanyakan preferensi program berasal dari promosi dari media televisi tentang acara-acara televisi yang ditawarkan atau malah dari teman sebaya yang juga menonton acara televisi. Tak jarangprogramkartunyang ditonton disesuaikan dengan waktu luang yang dimiliki oleh para informan.

Perbedaan gender juga menjadi faktor utama dalam memilih jenis film kartun yang ditonton, laki-laki lebih banyak menonton film-film kartun berbau Superhero atau Detektif seperti Power Ranger, Tom and Jerry dan lainnya, sedangkan untuk perempuan lebih banyak menikmati

Di Televisi Edukasi" vol. 11, nomor 2, (Jakarta:Universitas Esa Unggul, September 2014). 88 film kartun seperti Dora the Explore, Putri Salju dan lain sebagainya. ${ }^{6}$

1. Hambatan dalam komunikasi

Dalam berkomunikasi tentunya seringkali pesan atau informasi mengalami hambatan-hambatan. Jenis hambatan yang sering dialami komunikator dalam menyampaikan pesan cukup beragam diantaranya adalah:

a. Hambatan semantik, yaitu hambatan yang berasal dari komunikator ketika menyampaikan pesan sebab salah ucap atau tulis dapat menimbulkan salah pengertian(misunderstanding) atau salah tafsir (misinterpretation) yang pada gilirannya bisa menimbulkan salah komunikasi (miscommunication). Menurut OnongUchjanaEfendy dalam buku dinamika komunikasi, Sering kali salah ucap disebabkan komunikator berbicara terlalu cepat sehingga ketika pikiran dan perasaan belum mantap terformulasikan, kata-kata sudah terlanjur dilontarkan. Gangguan semantis kadangkadang disebabkan pula

6 Reni Triwardani "Kajian Kritis Praktik Anak Menonton Film Kartun di Televisi Dalam Aktifitas Keseharian di Banyuwangi” vol. 9, nomor 1, (Yogyakarta, UKP, Januari 2007). 53 
oleh aspek antropologis, yakni kata-kata yang sama bunyinya dan tulisannya, tetapi memiliki makna yang berbeda.

b. Hambatan mekanis, hambatan mekanis dijumpaipada media yang dipergunakan dalam melancarkan komunikasi. Banyak contoh yang kita alami dalam kehidupan sehari-hari, suara telepon yang tidak jelas, ketika huruf buram pada surat, suara yang hilang-muncul pada pesawat radio, berita surat kabar yang sulit dicari sambungan kolomnya, gambar yang meliuk-liuk pada pesawat televisi, dan lain-lain.

c. Hambatan ekologis, hambatan ekologis yang terjadi disebabkan oleh gangguan lingkungan terhadap proses berlangsungnya komunikasi, jadi datangnya dari lingkungan. Contoh hambatan ekologis adalah suara riuh orang-orang atau kebisingan lalu-lintas, suara hujanataupetir, suarapesawat terbang lewat, dan lain-lain. Situasi komunikasi yang tidak menyenangkan seperti itu dapat diatasi komunikator dengan menghindarkannya jauh sebelum atau dengan mengatasi pada saat ia sedang berkomunikasi. Untuk menghindarkannya komunikator harus mengusahakan tempat komunikasi yang bebas dari gangguan-gangguan tersebut. $^{7}$

Selain komunikator, hambatan juga sering datang dari komunikan sebagai penerima informasi. Manusia sebagai mahluk heterogen tentunya memilki kecendrungan yang berbeda-beda, senada dengan teori komunikasi uses and gratification yang menyatakan bahwa komunikan berhak memilih sendiri tayangan atau informasi yang relevan dengan dirinya sendiri. Faktor psikologis juga mempengaruhi proses komunikasi Setidak-tidaknya ada tiga faktor psikologis yang mendasari hal itu yaitu:

1. Selective attention. Orang biasanya cenderung untuk mengekspos dirinya hanya kepada hal-hal (komunikasi) yang dikehendakinya. Misalnya, seseorang tidak berminat membeli mobil, jelas dia tidak akan berminat membaca iklan jual beli mobil.

7 Danur Ardiansyah, "hakikat pesan dalam komunikasi", dalam www.academia. edu/artikel diakses tanggal 17 Januari 2018, pukul 08:05 
2. Selective perception. Suatu kali, seseorang berhadapan dengan suatu peristiwa komunikasi, maka ia cenderung menafsirkan isi komunikasi sesuai dengan prakonsepsi yang sudah dimiliki sebelumnya. Hal ini erat kaitannya dengan kecendrungan berpikir secara stereotip.

3. Selective retention. Meskipun seseorang memahami suatu komunikasi, tetapi orang berkecenderungan hanya mengingat apa yang mereka ingin untuk diingat.

1. Pesan Moral

a. Pengertian pesan

Pesan merupakan seperangkat simbol verbal dan / non verbal yang mewakili perasaan, nilai, gagasan atau maksud sumber tadi. pesan itu menurut Onong Effendy, menyatakan bahwa pesan adalah : "suatu komponen dalam proses komunikasi berupa paduan dari pikiran dan perasaan seseorang dengan menggunakan lambang, bahasa/lambang-lambang lainnya disampaikan kepada orang lain”.

Pesan mempunyai tiga komponen: makna, simbol yang diguankan untuk menyampaikan makna, dan bentuk atau organisasi pesan. Simbol terpenting adalah kata-kata (bahasa), yang dapat merepresentasikan objek (benda), gagasan, dan perasaan, baik ucapan (percakapan, wawancara, diskusi, ceramah, dan sebagainya) ataupun tulisan (surat, esai, artikel, novel, puisi, pamflet, dan sebagainya). Katakata memungkinkan kita berbagi pikiran dengan orang lain. Pesan juga dapat dirumuskan secara non verbal, seperti melalui tindakan atau isyarat anggota tubuh.

Beberapa unsur yang harus ada dalam sebuah pesan agar menjadi pesan yang efektif diantaranya adalah sbb:

1. Kode pesan adalah sederetan simbol yang disusun sedemikian rupa sehingga bermakna bagi orang lain

2. Isi pesan adalah bahan untuk atau materi yang dipilih yang ditentukan oleh komunikator untuk mengomunikasikan maksudnya.

3. Wujud pesan adalah sesuatu yang membungkus inti pesan itu sendiri, komunikator memberi wujud nyata agar komunikan tertarik akan isi pesan didalamnya. ${ }^{8}$

b. Pengertian moral

Istilah moral berasal dari kata latin "mos" (moris), yang berarti adat 8 Ibid, 
istiadat, kebiasaan, peraturan/ nilai atau tatacara kehidupan. Sedangkan moralitas merupakan kemauan untuk menerima dan melakukan peraturan, nilai-nilai atau prinsipprinsip moral.

Al-Ghazali mengemukakan pengertian akhlak sebagai padanan kata moral, sebagai perangai (watak, tabiat) yang menetap kuat dalam jiwa manusia dan merupakan sumber timbulnya perbuatan tertentu dari dirinya secara mudah dan ringan, tanpa perlu dipikirkan dan direncanakan sebelumnya. Ada empat makna etika menurut imam Al-Ghazali yaitu perbutan baik dan buruk, kemampuan untuk melakukan keduanya, kemampuan untuk mengetahui keduanya dan kecendrunganjiwakepadaperbuatan baik dan buruk. ${ }^{9}$

Dalam agama islam ahlak atau moral secara umum dibagi menjadi dua macam yakni akhlak yang baik (ahlakul karimah) dan ahlak yang buruk (ahlakul mazmumah). Ahlakul karimah dalam pergaulan sehari-sehari sangatpenting untuk diperhatikan. Karena seringkali sebuah permasalahan lahir karena seseorang tidak dapat berahlak dengan baik terhadap sesamanya. Ahlakul karimah dapat berorientasi

9 Staff.uny.ac.id daikses tanggal 1 Februari 2018 pada beberapa tempat diantaranya adalah :

a. Ahlakul karimah pada Allah SWT, diantaranya adalah percaya pada hukum allah, menjalankan ibadah, menjauhi larangan dan masih banyak lagi

b. Ahlak karimah pada diri sendiri, diantaranya adalah optimis, berkreasi, pemurah dan rela berkorban.

c. Ahlakul karimah pada sesama manusia, diantaranya adalah berbakti kepada orang tua, suka menolong sesama, menyayangi yang lemah dan lain sebagainya. 10

Sedangkan ahlakul mazmumah adalah ahlak tercela yang sepatutnya tidak dikerjakan oleh orang islam yangberiman kepada Allah SWT. Seseorang dikatan memilki ahlak tercela apabila melakukan perbuatan yang tercela secara terus menerus. Berikut beberapa contoh ahlak mazmumahyangseringterjadidalam kehidupan masyarakat baik yang disadari ataupun yang tidak disadari. Daiantaranya adalah dengki, sifat iri hati, sifat angkuh, dan sifat riya. ${ }^{11}$

10 Bimbie.com ilmu pengetahuan agama/ahak-remaja diakses tanggal 8 Februari 2018

11 Ma'ruf Syafi'I, artikel inspirasi. Diakses tanggal 8 Februari 2018 
Perkembangan moral seorang anak banyak dipengaruhi oleh lingkungannya, khususnya dilingkungan keluarga. Dalam perkembangan moral seorang anak, peran orang tua sangatlah penting terutama ketika masih kecil dan baru mengenal dunia. ${ }^{12}$

Selain keluarga, moral anakanak juga dibentuk dari kondisi lingkungan tempat tinggal dan teman bermain. Kehidupan anak-anak pedesaan tentunya sangat berbeda dengan kehidupan anak-anak yang hidup dilingkungan perkotaan. Dedi Kurniawan dalam bukunya menjelaskan bahwa perkotaan adalah tempat untuk membentuk prilaku manusia. Prilaku ini terbentuk karena ada stimulus yang kemudian diterima dan direspon oleh masyarakat berdasarkan ilmu pengetahuan dan pengalaman. ${ }^{13}$

\section{B. Bentuk komunikasi}

\section{Pendongeng dalam Media TV}

Dalam

program-program dongeng tentunya pendongeng memiliki perananan penting dalam menyampaikan pesan, tentunya pesan disampaikan melaui proses komunikasi secara verbal dan

12 Syamsu Yusuf LN, Psikologi Perkembangan Anak dan Remaja, (Bandung: Remaja Rosda karya, 2005), 132-133

13 Dedy Kurniawan Halim, Psikologi Kehidupan Perkotaan, (Jakarta: Sinar Grafika Offset, 2008). 13 non verbal. Jenis komunikasi ini sebagaimana dijelaskan oleh Kelley dan Hovlan bahwa kedua jenis komunikasi ini sangat relevan dalam memberikan stimulus dan mengubah sikap orang. Komunikasi verbal digunakan pndongeng ketika membuka, menyampaikan isi daongeng dan menutup dongeng. Selain bahasa verbal pendongeng juga menyampaikan dongeng menggunakan bahasa nonverbal untuk menguatkan bahasa verbal. Dalam hal ini komunikasi nonverbal banyak digunakan dalam bentuk gambar, mimik wajah dan geraak tubuh. Mimik wajah dan gerak tubuh biasanya pendongeng gunakan ketika terdapat sebuah adegan dalam dongeng yang tidak dapat dibahasakan secara verbal atau untuk memperjelas bahasa verbal dari dongeng, dalam dongeng Dende Winangsie pendongeng mempragakan ketika sang pangeran membuka baju penyamarannya. ${ }^{14}$

Pak Sahlan selaku narasumber dongeng dalam program bedongeng juga menyatakan bahwa komunikasi verbal dan non verbal harus seimbang.

"Ketika menyampaikan dongeng di media harus seimbang antara cerita dan gambar, nah ini yang bikin repot ketika harus bercerita

14 Observasi, tanggal 10 Maret 2018 
kemudian dibarengi dengan menggambar. Ya, otak kanan dan kiri harus kerja, pokoknya harus seimbang lah antara gambar dengan bicaranya." ${ }^{15}$

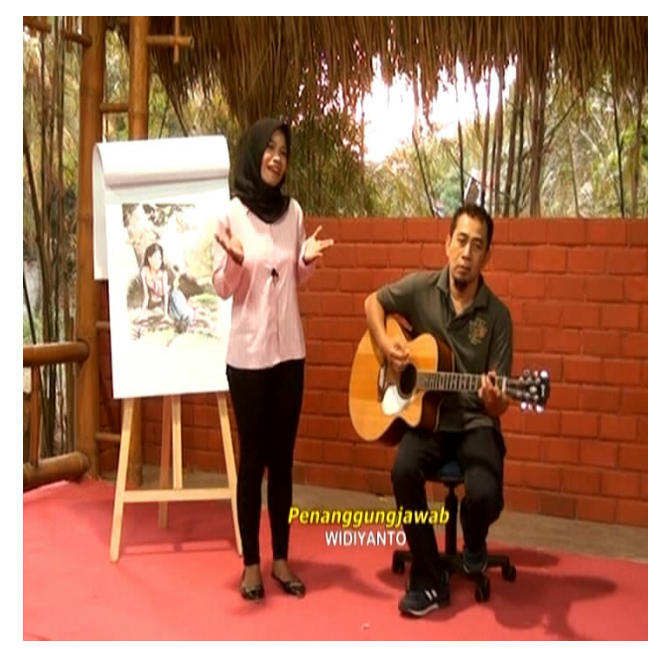

Gambar: Proses berdongeng di Televisi

Mendongeng merupakan salah satu bentuk edukasi menggunakan bahasa yang mudah dimengerti oleh pemirsa. Dari hasil observasi, Penulis menemukan bentuk komunikasi yang digunakan oleh pendongeng ketika mendongeng adalah dengan menggunakan bahasa yang santun, dan mudah dimengerti khususnya oleh anak-anak. Dongeng juga pendongeng bawakan dengan intonasi yang pelan, dan kadang dibarengi dengan mimik muka yang mengilustrasikan perasaan yang sedang di rasakan oleh tokoh dalam dongeng. ${ }^{16}$

15 Wawancara, Pak Sahlan, pendongeng 26 Februari 2018

16 Observasi, tanggal 10 Maret 2018

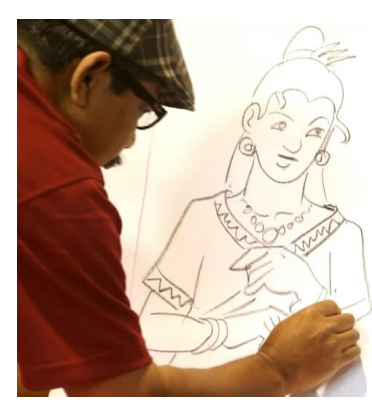

\section{Gambar: ilutrasi Putri Mandalika}

Pak Sahlan juga menjelaskan bahwa ketika mendongeng itu seorang pendongeng terlebih dahulu harus melakukan seleksi terhadap dongeng-dongeng sebelum disampaikan kepada khalayak, karena menurutnya banyak sekali dongeng daerah yang kurang layak untuk dikonsumsi anak-anak.

"Karena dongeng untuk anakanak, seringkali saya kesulitan untuk menentukan dongeng yang benar-benar cocok, pas, layak, menarik dan pokoknya memenuhi kriteria. ${ }^{17}$

Maka dari itu pak Sahlan menyatakan bahwa seorang pendongeng harus cerdas dalam memilah dongeng agar pesan yang diterima oleh pemirsa lebih baik. Diantara bagian-bagian dongeng yang tidak layak disampaikan kepada anak-anak menurut pak Sahlan

17 Wawancara, Pak Sahlan, pendongeng 26 Februari 2018 
adalah pembunuhan, pencurian, pacaran, kekerasan dan bahkan sangat vulgar. Namun walaupun demikian paling tidak permasalahan diatas bisa diminimalisir atau ketika berdongeng tidak menceritakan kronologis kejadian secara rinci, cukup secara umum.

"Walaupun demikian kan kita juga tidak bisa menghindari karena disetiap dongeng ada saja bagianbagian konfliknya. Saya pernah ikut lomba dulu kebetulan dongeng saya tentang laba-laba, biar seru saya bangun konflik dalam ceritanya biar nanti yang menzalimi itu ceritanya bisa seru, biar endingnya nanti si jahat ini sadar dan minta maaf. Nah kan sebelum itu kita harus membuat dulu bagaimana ia menzolimi lawannya, ketika diskusi bagian ini yang menjadi permasalahannya karena proses menzolimi orang ini kurang pantas untuk disampaikan kepada anak-anak."

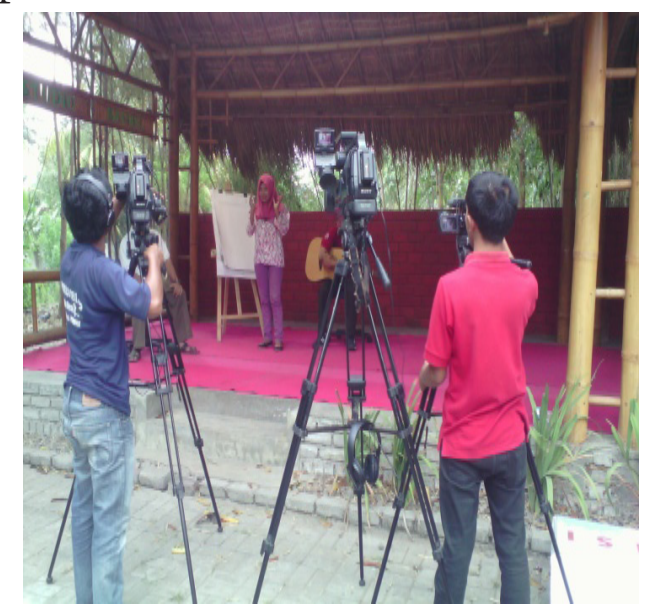

Gambar: siaran langsung di TV
Dijelaskan pula oleh produser program acara bedongeng bahwa dalam bedongeng ini dibutuhkan ketelitian dalam memilah dongeng yang akan dibawakan

"dongeng yang diceritakan kan bukan hanya untuk menghibur untuk anak-anak, tapi ketika menyimak dongeng anakanak juga bisa dapat ilmu dan pengetahuan baru "18

Pak sahlan juga menceritakan bahwa pada satu segmen, pernah membawakan dongeng tentang Dende Cilinaye yang dibunuh, tapi diceritakan sepintas saja. Selain kekerasan fisik, cerita yang terlalu ajaib juga kurang cocok untuk anak-anak karena anakanak juga harus diajarkan logikalogika cerita agar paham, selain itu ketika menyampaikan pesan yang terkandung dalam sebuah dongeng harus secara tersirat.

Terkait bentuk komunikasi yang digunakan dalam proses bedongeng, Ernita selaku pemandu program yang sekaligus juga menjabat sebagai produser acara menjelaskan

"kalo masalah bentuk komunikasi yang digunakan kita serahin ke pak Sahlan, kan beliau ahlinya kalo masalah dongeng.

18 Wawancara, Ernita, produser sekaligus pemandu acara 8 Mei 2018 
Ya pokoknya kalo beliau yang bawain dongengnya kayak hidup banget"

Informan diatasjuga menjelaskan bahwa dalam proses bedongeng memangdibutuhkankeahliankhusus karena dongeng yang dibawakan bukan dongeng sembarangan.

"ini kan kebanyakan dongeng anak ya, tentunya dongengnya harus di pilih-pilih mana yang tepat dikonsumsi oleh anakanak" $^{\prime 19}$

Dalam setiap dongeng yang dibawakan, pendongeng kadang tidak menjelaskan langsung pesan moral yang terkandung dalam dongeng, melainkan menanyakan langsung kepada presenter terkait pesan moral yang ditangkap dari setiap dongeng yang dibawakan. ${ }^{20}$

Pak Sahlan menjelaskan mengenai penyampaian pesan moral ketika bercerita lebih baik melalui cerita agar dongeng tidak terkesan menggurui.

"Tidakgampanguntukmengatur bahasa dan pilihan kata dalam mendongeng maka dari itu dongeng jangan diremehkan, karena dongeng merupakan sebuah peluang untuk orang tua

19 Wawancara, Ernita, produser sekaligus pemandu acara 8 Mei 2018

20 Observasi, tanggal 17 Maret 2018 ataupendongengmenyampaikan pesan-pesan yang layak dikonsumsi seperti pesan moral, agama, sosial, edukasi, budaya dan pesan-pesan lainnya"21

Pak Sahlan juga menceritakan kalau membaca dongeng-dongeng dari negara-negara lain seperti Inggris itu pasti mengandung pesan untuk prestasi perubahan nasib.

"Seperti walaupun dari kalangan anak kampung tapi harus memilki istri dari keturunan yang lebih tinggi, pak Sahlan mengutip pernyataan dari Mic Len yaitu need of acheivement. Prestasi ini tentunya didapat dari hasil perjuangan yang dilakukan untuk mendapatkan tujuannya"

Berbicara tentang strategi dalam berdongeng, pak Sahlan juga mengungkapkan bahwa dalam membawakan dongengnya tidak dibarengi dengan tehnik atau trik khusus.

"Ini karena programnya sudah menarik jadi menurut saya tidak perlu ada trik khusus untuk menarik anak-anak, kalo menurut saya disinalah fungsi dari orang tua untuk membimbing anak menonton

21 Wawancara, Pak Sahlan, pendongeng 26 Februari 2018 
TV memilihkan program yang tepat untuk ditonton"

Hanya saja untuk memudahkan dan lebih menarik perhatian, pak Sahlan membuat trobosan baru.

"Awalnya dulu kan tanpa sketsa, saya menggambar langsung pada kertas sambil mendongeng, tapi lama kelamaan saya berfikir terlalu lambat bahkan kadang gambarnya kurang jelas untuk mengilustrasikan cerita. Kadang saya juga berfikir apa anakanak tidak bosan dengan hanya menggunakan satu warna.

Untuk membantu mengingat alur cerita pak Sahlan membuat langkah baru dengan membuat gambar jadi yang kemudian tinggal diwarnai ketika rekaman. Namun cara baru yang diterapkan oleh pak Sahlan ini terkadang membutuhkan konsentrasi ketika mewarnai, sehingga dalam beberapa segmen memakan waktu yang cukup lama dibandingkan dengan cara lama yang digunakan ketika bedongeng yang hanya menggunakan gambar sederhana seperti pada tayangan perdana program bedongeng.

Dalam beberapa segmen bedongengyangPenulisikutiterdapat beberapa adegan dimana kadang pendongeng fokus menggambar sehingga lupa melanjutkan ceritanya, atau sebaliknya ketika sedang fokus bercerita pendongeng lupa mewarnai sehingga gambar di balik ulang untuk diwarnai. ${ }^{22}$

Terkait hal tersebut pak Sahlan kembali menjelaskan bahwa waktu yang diberikan pihak selaparang cukup panjang.

"TapiuntunglahpihakSelaparang TV tidak memberikan batasan waktu, mau ceritanya panjang atau pendek yang penting cerita terus sampai habis. Masalah durasi kan kalu melebihi nanti bisa di edit lagi sama editor, bisa dipotong-potong diambil gambar yang memang pas gitu"

Terkait durasi Penulis juga melakukan wawancara dengan kepala bagian produksi yaitu Sima Rista, dalam wawancara tersebut dijelaskan bahwa durasi untuk setiap produksi mencapai 30 menit. ${ }^{23}$

\section{E. Penutup}

Bentuk komunikasi yang digunakan oleh pendongeng dalam menyampaikan pesan moral adalah melalui pesan verbal dan nonverbal yang didukung dengan media televisi sebagai media publikasi, sehingga proses komunikasi yang terjadi

22 Observasi, tanggal 10 Maret 2018

23 Wawancara, Sima Rista, kabag produksi 26 Februari 2018 
adalah proses komunikasi sekunder. Adapun pesan moral religius yang disampaikan pendongeng melalui program bedongeng diantaranya adalah sebagaiberikut; a). membantu orang lain, b). selalu meminta dan memohon kepada Allah SWT, c). membalas keburukan dengan kebaikan, d). perjuangan harus pula disertai dengan do'a, e). berbakti kepada orang tua, f). jangan pernah tamak dan sombong terhadap harta, g). jangan mengingkari janji, h). jangan pernah menyimpan rasa iri hati dan dendam, serta bersikap dewasa dalam menghadapi masalah i). jangan pernah berburuk sangka (su'udzan)terhadaptakdir AllahSWT. Sedangkan hambatan-hambatan yang sering terjadi dalam program bedongeng diantaranya adalah a). hambatan Semantik, berasal dari komunikator, b). hambatan dari komunikan, c). hambatan ekologis, suara alam bebas yang ikut terekam oleh clip on, d). hambatan teknis, yakni hambatan yang berasal dari peralatan-peralatan yang digunakan pada proses rekaman.

\section{Daftar Pustaka}

Ardiansyah, Danur, "Hakikat Pesan dalam Komunikasi”, dalam www.academia.edu/artikel diakses tanggal 17 januari 2018.

Bimbie.com

Cangara, H. Hafied, Pengantar Ilmu Komunikasi, (Jakarta: Raja Grafindo Perkasa, 2007)

Halim, Dedy Kurniawan, Psikologi Kehidupan Perkotaan, (Jakarta: Sinar Grafika Offset, 2008)

Kuswandi, Wawan, Komunikasi Massa Sebuah Analisis Media Televisi, (Jakarta: Rineka Cipta,1996)

Kuswita, Hery, Perencanaan dan Produksi Program Televisi Pendidikan Di Televisi Edukasi, (Jakarta:Universitas Esa Unggul, September 2014).

Staff.uny.ac.id

Sudibyo, Agus, Ekonomi Politik Media Penyiaran, (Yogyakarta, LkiS, 2004).

Triwardani, Reni, "Kajian Kritis Praktik Anak Menonton Film Kartun di Televisi Dalam Aktifitas Keseharian di Banyuwangi" (Vol. 9. No. 1, Januari 2007).

Yusuf LN, Syamsul, Psikologi Perkembangan Anak dan Remaja, (Bandung: Remaja Rosda karya, 2005). 